\title{
Location and Gender Differences in Deviant Behavior among
}

\section{Primary School Teachers}

\author{
Dr. Muhammad Sarwar (Corresponding author) \\ Department of Education, University of Sargodha, Sargodha, Pakistan \\ Tel: 92-321-860-0055E-mail: drsarwar@ymail.com \\ Dr. Riffat-un-Nisa Awan \\ Department of Education, University of Sargodha, Sargodha, Pakistan \\ Tel: 92-300-600-9104Ｅ-mail: riffarukh@yahoo.com \\ Muhammad Alam \\ Department of English, University of Sargodha, Sargodha, Pakistan \\ Dr. Muhammad Nadeem Anwar \\ Department of Education, University of Sargodha, Sargodha, Pakistan \\ Tel: 92-321-775-0500Ｅ-mail: dr.nadeem@ymail.com
}

\begin{abstract}
Any behavior that does not conform to social organizational norms is considered deviant. Observing school timings, teaching classes regularly and behaving properly with students and colleagues are basic school norms. This study was conducted to test whether there is any deviation in organizational, interpersonal, behavior, among rural-urban male-female primary school teachers. The results revealed higher organizational deviations among primary school teachers as compared to interpersonal deviation. Male teachers show greater degree of deviation. The remedial measures demand incentives (performance based promotion), motivation, appreciation, proper monitoring system and training facilities.
\end{abstract}

Keywords: Organizational behavior, Deviant behavior, Gender, Location, Primary school, Teachers

\section{Introduction}

Every organization embodies a set of behaviors, which have to be observed for the accomplishment of objectives. Any behavior that does not conform to social organizational norms is said to be deviant behavior. Workplace deviance in behavior violates organizational norms and threatens the organization (Robinson and Benett, 1995). In school every teacher is expected to observe specified institutional rules and regulations. If a teacher does not observe these specified behaviors such as school timings, teaching assignment and desired behavior with students and colleagues, shows deviant behavior. Sackett, et al (2006) investigated that counterproductive workplace behaviour is a distinct construct. Successful organizational settings have employees who do more than their job duties and avoid workplace deviant behavior (Robbins, 1998).

In school situation, following school timings, teaching classes regularly and behaving properly with students and colleagues are basic expected school norms. Robinson and Kelly (1998), highlight that individuals’ anti-social behaviours are shaped by the influence of their co-workers, as they found significant relationship between the level of anti-social behavior exhibited by newly inducted individuals, and that which was exhibited by their co-workers. They visualized that the newly recruited teachers usually work honestly in the beginning of their career but after some time they also indulge in the same type of deviant behavior.

Weak monitoring system in education does facilitate continuity in deviant behaviour. Professional training and due incentives do play important role to develop an important role in promoting positive behaviours and desired practices. In other words there in lack of justice in public school system in the Punjab (Pakistan). Indifferent attitudes and practices of the administration predict work place deviance (Aquino, Lewis, and Bradfield, 2000). Naturally when employees put their time and effort in work they expect to be treated justly. 
Lack of justice affects the hard working and honest teachers, which results in change in the working environment. They tend to be de-motivated by long spells of injustice and lack of attention. $\operatorname{Lim}(2002)$ explored the extent that those the employees who put in time and efforts to fulfill their duties, expect to be treated fairly by their employers. When employers fail to reciprocate, it becomes all too easy for the employees to withdraw efforts for the organization through such acts as workplace deviance.

Deviant behaviour is harmful for the school and students in all its forms, whether it is overt or covert. Appelbaum, Iaconi and Matousek (2007) found that regardless of whether negative deviance is overt or implicit, it has negative consequences for the entity and its affiliates. School deviation behaviour may vary from minor (leaving workplace for short time during working hours) to serious (physical fights with colleagues). Robinson and Bennett (1995) mentioned these two dimensions of deviant workplace behaviours: minor to serious, and interpersonal to organizational.

Sarwar, Yusuf and Hussein (2010) explored that political transfers and political interference develops negative attitude among teachers. Bolin and Heathery (2001) used four attitude variables (theft approval, company contempt, intent to quit, and dissatisfaction) to predict four types of deviant employee behaviour (absenteeism, substance abuse, privilege abuse, and theft). He concluded that each attitude has a specific and stable pattern of relationships with the four types of deviance.

Judge, Scott and Ilies (2006) explored that workplace deviant behaviour can be intra-individual or inter-individual phenomenon. There are many theories of workplace deviation. Clinard and Meier (2008) mentioned four major social deviation theories: First, Cultural Transmission Theory states that society usually encourages a respect for cultural norms, but that if a person is in an environment where people do not follow cultural norms he too will ignore cultural norms. Second, Structural Strain Theory explains deviance as a result of social strains put on people. This social strain may be the result of a contradiction, when socially approved goals cannot be met by using socially approved means. Third, Control Theory explains deviation as a failure of society to conform a person to its norms. Forth, Labeling Theory puts deviation into two stages. Primary Deviance is temporary, exploratory, trivial, and/or easily concealed. In Secondary Deviance non-conformity persists in the person.

School deviant behavior has become a major problem in Pakistan. In public schools in Pakistan, teachers are attracted less by an interest in imparting education than by the job security provided by state as opposed to private schools (international crisis group, 2010). A study of workplace deviation is necessary to solve the problem of workplace deviation in Pakistan. This study was conducted to test the following hypothesis

1. There is no difference in organizational deviance and interpersonal deviant behavior of primary school teachers

2. There is no difference in work place deviant behavior of male and female primary school teachers

3. There is no difference in work place deviant in urban and rural primary school teachers

4. There is no difference in work place deviant behavior in male and female teaching staff?

\section{Method}

To check these hypotheses, a survey research was conducted. The researcher approached primary school teachers in Gujranwala city personally. They were enrolled in a course of primary school teachers organized by directorate of Staff development. The teachers were requested to participate in the study. About $60 \%$ were ready to respond the scale. They were called out and questionnaire was handed over to them along with the cover letter and verbal instructions. They filled in the questionnaire as per their convenience.

\section{Instrument}

The workplace deviation behaviour scale used by Chandler (2008) developed by Robinson and Bennett (2000) was adapted to collect data. The original scale was 7-point (never, once a year, twice a year, several times a year, monthly, weekly, and daily). The scale was also translated into Urdu. The bilingual version of the scale was discussed with a group of primary school teachers. The majority of teachers suggested that 5-point scale will be better than 7-point scale. Hence, it was decided to change the scale from 7-point to 5-point. The final scale comprised of three parts; part one comprised of 7 items (1-7), that show the interpersonal deviance (deviant behavior directly harmful to other individuals within the organization). Part two comprised of 12 items that show organizational deviance (deviant behavior directly harmful to organization). Respondents were requested to indicate the extent to which they are engaged in each of the behaviors on a 5-point Likert scale. The scale anchors were as follows: never, rarely, sometimes, often and always. The third part consisted of two open 
ended questions: why workplace deviant behavior has developed, how work place deviant behavior can be improved. The Cronback alpha for the scale was .749.

\section{Results}

The table 1 shows that the primary school teachers show higher organizational deviations as compared to interpersonal deviation. This might be due to by the job security provided by state as opposed to private schools (international crisis group, 2010). In Pakistan sometimes due to political interference, peons control the primary schools and do care the norms of the school. Weak monitoring system may be another cause of more organisational deviance as opposed to interpersonal deviations.

The table 2 shows that there is no significant difference in the means of urban and rural school deviation of primary school teachers. Primary schools are the most neglected area of even public educations system. In urban primary schools only the children of low soci-economic status attend government primary schools. The children of political leaders and bureaucracy do not attend government schools, even the children of senior officers in schools cadre attend private schools.

Above table 3 shows show that there is significant difference in male workplace deviation, and organizational deviation of male and female primary school teachers. As far as interpersonal deviation behavior is concerned there is no difference in deviation behavior of males and females. As the male in Pakistani culture have more social responsibilities and there is no restriction on free movement of the male in society, they tend to move out of school in school hours to fulfill their social responsibilities and contact their senior officers for soft corner. That is why they show more organizational deviant behavior as compared to their female counter parts.

The table 4 shows that there is no difference in workplace deviance, interpersonal deviance and organizational deviance. Hence, the effect of the independent variable "qualification" was not significant. In other words, a non-significant F-statistic shows that the school, interpersonal, and organizational deviations of teachers are not related to their professional and academic qualifications.

The synthesis of open ended questions revealed that the school system of Pakistan was mainly damaged by political appointments and interference in 80 's and 90's. The members of national and provincial assemblies were publically working against merit. A teacher recalled the words of a member of provincial assembly "we (Members of Provincial assembly) have asked the educational authorities not to appoint teachers on merit and we will ensure that". Approval of theft (giving less than stipulated time to school), school contempt, intent to quit the job and dissatisfaction with the job can predict school deviant behaviour. One of the teachers who used to come late to school on asking about the reason to come late explained "the government is not fulfilling my needs properly that is why I am not giving full time to school." Usually teachers, who are recruited on political grounds, remain loyal to their political masters and do not perform their duties well. These politically recruited peoples provide example to others for school deviant behaviour. In Pakistan heads of the schools are unable to control workplace deviance of some of the teachers due to their political backgrounds. When other teachers see that one of their colleagues is being spared, they think that they are being subjected to unjustified treatment, they also tend to show deviant behaviour. In this way school deviant behaviour is also affected by perceived interpersonal justice.

\section{Discussion}

Primary school teachers show higher organizational deviations as compared to interpersonal deviation. This might be due to by the job security provided by state as opposed to private schools (international crisis group, 2010). This situation has mainly arisen from decade's impunity, lack of proper training and incentives. The teachers showing deviant behaviour usually have connections with high ups in the department. If the head of the institution tries to stop their deviant behaviour, they use their influence to withdraw the action against them. This situation can be avoided if the Assistant Education officers (AEO's) and Deputy Education Officers (DEO,s) are appointed on merit. Highly educated and honest peoples are available in Pakistan. The need is to advertise these posts properly and selection may be through a search committee consisted of honest and competent officers who are abreast of ground realities. After appointment they should be provided security and proper powers to mend the situation.

As the monitoring system is same in urban and rural school, there is no difference in the deviation behaviour of primary school teachers of urban and rural areas. Male primary school teachers show more workplace deviation, and organizational deviation than female primary school teachers. As the male in Pakistani culture have more social responsibilities and there is no restriction on free movement of the male in society, they tend to move out of school in school hours to fulfill their social responsibilities and contact their senior officers for soft corner. 
That is why they show more organizational deviant behavior as compared to their female counter parts. It is worth mentioning that there is no difference in interpersonal deviation behavior of males and females. Qualification plays no role in workplace deviance, interpersonal deviance and organizational deviance.

Through review of related literature, it is suggested that rewards, incentives, feedback, motivation and appreciation may be used to reduce school deviations. Positive reinforcement increases the occurrence of an appropriate response. Shaping, discussion, communication, participation and discrimination strategies are used to encourage employees to show their behavior perfectly. Sometimes, unwanted techniques like delayed promotions, extinction, warning etc may be used to improve the situation.

\section{Conclusion}

Primary school teachers show higher organizational deviations as compared to interpersonal deviation. This situation has mainly arisen from decade's impunity, lack of proper training and incentives. Rewards, incentives, feedback, motivation and appreciation may be used to reduce school deviations. Punishment may be used in rare cases. There are no residential and qualification wise differences in school deviation. The male show greater deviation due to social responsibilities.

\section{References}

Appelbaum, S. H., Iaconi, G. D., \& Matousek, A. (2007). Positive and negative deviant workplace behaviors: causes, impacts, and solutions. Corporate Governance, 7(5), 586 - 598

Aquino, K., Lewis, M. U. 1., \& Bradfield, M. (2000). Justice constructs, negative affectivity, and employee deviance: a proposed model and empirical test. Journal of Organizational Behavior, 20 (7), 1073 - 1091

Bolin, A., \& Heathery, L. (2001). Predictors of employee deviance: the relationship between bad attitudes and bad behavior. Journal of business and psychology, 15(3), 405-418

Clinard M. B., \& Meier R. F. (2008). Sociology of Deviant Behaviour. Wardsworth cengage learning, U. K.

International crisis group. (2010). Reforming Pakistan Civil Service. Crisis Group Asia Report N-185

Judge, T.A., Scott, B.A., \& Ilies. R. (2006). Hostility, Job Attitudes, and Workplace Deviance:Test of a Multilevel Model. Journal of Applied Psychology, 91(1), 126-138

Lim, V. K. (2002). The IT way of loafing on the job: cyberloafing, neutralizing and organizational justice. Journal of Organizational Behavior, Vol: 23, Issue 5: 675-694

Robbins, S.P. (1998). Organizational behavior: Concepts, controversies and applications. Englewood Cliffs: Prentice-Hall.

Robinson, S. L., \& Leary-Kelly, A.M. (1998). Monkey see, monkey do: The influence of work groups on antisocial behavior of employees. Academy of Management Journal, 41(6), 658-672.

Robinson, S.L., \& Bennett, R.J. (1995). A typology of deviant workplace behaviors: A multidimensional scaling study. Academy of Management Journal, 38(2), 555-572.

Sackett, P.R., Berry, C.M., Wiemann, S.A., \& Laczo, R.M. (2006). Citizenship and counterproductive behavior: clarifying relations between the two domains work place deviation behaviour. Human Performance, 19(4), $441-464$

Table 1. Comparison of means of interpersonal and organisational deviations behaviour of primary school teachers

\begin{tabular}{l|c|r|r|c|c|c}
\hline Deviation & N & \multicolumn{1}{c|}{ Mean } & Std. Deviation & df & F & Sig. \\
\hline Organizational & 68 & 20.7206 & 5.40549 & \multirow{2}{*}{130} & 15.65 & \multirow{2}{*}{.000} \\
\hline Interpersonal & 64 & 9.2344 & 2.36202 & & & \\
\hline
\end{tabular}


Table 2. Comparison of means of school deviations of urban and rural primary school teachers

\begin{tabular}{l|l|l|c|c|c|c|c}
\hline Deviation & Residence & \multicolumn{1}{l|}{ N } & Mean & Std. Deviation & Df & t & Sig: (2 tailed) \\
\hline \multirow{2}{*}{ Workplace } & Urban & 49 & 30.47 & 6.52 & \multirow{2}{*}{64} & .670 & .505 \\
\cline { 2 - 6 } & Rural & 17 & 28.67 & 1.51 & & & \\
\hline \multirow{2}{*}{ Interpersonal } & Urban & 49 & 9.28 & 2.36 & \multirow{2}{*}{64} & .616 & .540 \\
\cline { 2 - 5 } & Rural & 17 & 8.67 & 1.97 & & & \\
\hline \multirow{2}{*}{ Organizational } & Urban & 49 & 21.18 & 5.30 & \multirow{2}{*}{64} & .542 & .590 \\
\cline { 2 - 5 } & Rural & 17 & 20.00 & 1.55 & & & \\
\hline
\end{tabular}

Table 3. Comparison of means of school deviations of Male and Female primary school teachers

\begin{tabular}{|c|c|c|c|c|c|c|c|}
\hline Deviation & Residence & $\mathbf{N}$ & Mean & Std. Deviation & Df & $T$ & Sig: (2 tailed) \\
\hline \multirow[t]{2}{*}{ Workplace } & Male & 41 & 32.80 & 6.60 & \multirow{2}{*}{64} & \multirow{2}{*}{4.43} & \multirow{2}{*}{.000} \\
\hline & Female & 25 & 26.20 & 2.24 & & & \\
\hline \multirow[t]{2}{*}{ Interpersonal } & Male & 41 & 9.63 & 2.29 & \multirow{2}{*}{64} & \multirow{2}{*}{1.85} & \multirow{2}{*}{.069} \\
\hline & Female & 25 & 8.56 & 2.27 & & & \\
\hline \multirow[t]{2}{*}{ Organizational } & Male & 41 & 23.17 & 5.30 & \multirow{2}{*}{64} & \multirow{2}{*}{5.03} & \multirow{2}{*}{.000} \\
\hline & Female & 25 & 17.64 & 1.78 & & & \\
\hline
\end{tabular}

Table 4. ANNOVA showing the difference of group means on School deviation with different qualifications

\begin{tabular}{|c|c|c|c|c|c|c|}
\hline Deviation & $\begin{array}{l}\text { Sources of } \\
\text { Variance }\end{array}$ & \begin{tabular}{|l|} 
Sum of \\
Squares
\end{tabular} & Df & $\begin{array}{l}\text { Mean } \\
\text { Square }\end{array}$ & $\mathbf{F}$ & Sig. \\
\hline \multirow[t]{3}{*}{ Workplace } & Between Groups & 104.65 & 4 & 26.16 & \multirow[t]{3}{*}{.656} & \multirow[t]{3}{*}{.625} \\
\hline & Within Groups & 2433.29 & 61 & 39.89 & & \\
\hline & Total & 2537.94 & 65 & & & \\
\hline \multirow[t]{3}{*}{ Interpersonal } & Between Groups & 8.843 & 4 & 2.21 & \multirow[t]{3}{*}{.393} & \multirow[t]{3}{*}{.813} \\
\hline & Within Groups & 342.75 & 61 & 5.62 & & \\
\hline & Total & 351.59 & 65 & & & \\
\hline \multirow[t]{3}{*}{ Organizational } & Between Groups & 104.60 & 4 & 26.15 & \multirow[t]{3}{*}{1.016} & \multirow[t]{3}{*}{.406} \\
\hline & Within Groups & 1570.02 & 61 & 25.74 & & \\
\hline & Total & 1674.62 & 65 & & & \\
\hline
\end{tabular}

